\section{Mental handicap or learning disability}

\section{A critique of political correctness}

ANDREW H. REID

Political correctness originated in the multiracial environment of American university campuses in the late 1970s as an anti-racist movement. Initially it was a matter of politeness; there were certain pejorative terms about coloured people which were considered completely unacceptable. The movement took off in the 1980s, involving such issues as feminism, disability and multifaith religious education in schools, becoming a complex and increasingly pretentious code. Comparative literature espoused the cause and added its own absurdities: the works of Tolstoy and Shakespeare were written by deceased white males and of less literary significance than contemporary African folk stories. Psychiatric diagnosis fell victim: 'challenging behaviour', which can mean anything from eating too much or too little, to smoking or driving fast cars, replacing clinical diagnostic terminology.

The philosophy provoked a backlash. Not everything was equal. Political correctness had become mealy-mouthed and synonymous with mediocrity. The minority groups it was meant to champion found it effete and in many areas it was rejected. Some of the philosophy has persisted, however, and racist and sexist abuse is now, happily, widely regarded as unacceptable. Unfortunately, the mythology that it is possible to change the substance of the matter by changing the nomenclature has lived on in mental handicap.

Part of the history of mental handicap has been the search for a destigmatising terminology. The idiot, imbecile and moron of the 1913 UK legislation were replaced by mental deficiency in the 1959 Act, and subsequently by subnormality and severe subnormality, mental handicap, mental retardation and, now, learning disability (Gath, 1992). The term mental handicap had been introduced as an acceptable counterpart to physical handicap but objections came from the self-advocacy movement and those mentally handicapped people who DD2 5NF could express a view. They maintained that the public perception of 'mental' was of madness, and of 'handicap' was of physical disability and wheelchairs. They considered that misleading and unrepresentative of their condition and there was pressure to use the term 'learning disability' or 'learning diffculty', instead. These terms are, of course, synonymous in the public mind with primary educational problems such as dyslexia and, as such, are even more misleading. Moreover, who does not have a learning disability in some respect? Learning disability it was to be, however, and in 1991 Stephen Dorrell, then Minister of Health, announced that it was to be the official term. John Redwood, then Secretary of State for Wales, took a more robust line and the term was not accepted in the AllWales Strategy.

Now a range of parents with severely handicapped children state that the term 'learning disability' does not describe their child who is helpless and unable to move or speak. They accuse the Government of seeking to derecognise and undermine their need and right for support and services through euphemisms. It is full circle and we are reminded of Zigler \& Burack's (1989) comment that excessive deference to concerns about stigma can be counterproductive since "labels can often have positive consequences, particularly since they are often a necessary precondition to the receipt of services".

The debate is international. The International Association for the Scientific Study of Mental Deficiency is now the International Association for the Study of Intellectual Disability, and on the European scene the International League for Persons with Mental Handicap has now become Inclusion International - a term that means absolutely nothing. The term 'intellectual disability' is gaining ground and the principle scientific journal in the UK in the field of mental handicap is now the Journal of Intellectual Disability Research. Terminology in this field has a short shelf-life, however, and intellectual disability will probably go downhill before long also!

Against this background the Royal College of Psychiatrists has the worst of all possible worlds. Late in the day, and in the rearguard of politically correct opinion, the Section for the Psychiatry of Mental Handicap opted for the term learning disability in 1995. In so doing the College has chosen a term that is positively misleading, in that it implies that the problem is essentially educational, and that contains no suggestion of medicine or psychiatry. Moreover, the term has no currency outside the UK and the CCST for trainees will still be in 'mental handicap' to conform with the European Medical Directive (General Medical Council, 1996). The story will doubtless continue.

\section{REFERENCES}

Gath, A. (1992) Terminology and learning disability. British Journal of Hospital Medicine, 48.359.

Generd Modical Counch (199) The Speciolist Register - Foct Sheet. London: GMC

Zleler, E. \& Burack, f. A. (1969) Personality development and the dually diagnosed. Research in Developmental Disabilities, 10. 225-240.

ANDREW REID, FRCP, FRCPsych, DPM. Dundee Healthcare NHS Trust, Royal Dundee Liff Hospital, Dundee

(First received 14 May 1996, final revision 26 July 1996, accepted 6 August 1996) 